\section{Adverse outcomes in ambulatory anesthesia}

Frances Chung md frcpc, Gabor Mezei MD PhD

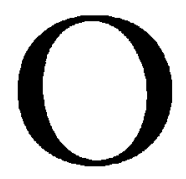

VER the past two decades surgical patient care has undergone a major change. While in the past, most of the surgical procedures required inpatient admissions, now most of the performed operations, an estimated $65 \%$ of operations in North America, are completed in ambulatory settings. The improvement of anesthetic and surgical techniques, which resulted in an extremely good safety record of ambulatory procedures, was a prerequisite for this radical increase in the number of surgical procedures performed in ambulatory surgical units. The purpose of this review is to examine what outcome measures can be used in the assessment of the safety of ambulatory surgery and anesthesia, and to summarize the available published results regarding these outcome measures (Table I).

\section{Mortality and morbidity}

The traditional measures of quality and safety of surgery and anesthesia are perioperative mortality and morbidity rates. These measures are readily applicable to ambulatory surgery and anesthesia, as well. However, mortality and morbidity rates are only rough measures, not necessarily reflecting the quality of care, but rather the overall health status of the patient population undergoing ambulatory surgery, which could differ from one surgical centre to another. The rarity of these events among ambulatory surgical patients, although it shows that the practice of ambulatory surgery is safe, further limits the use of these outcomes in quality assessment.

TABLE I Outcome measures in ambulatory anesthesia

\begin{tabular}{|c|c|}
\hline Mortality & $\begin{array}{l}\text { Immediate } \\
\text { Long-term }\end{array}$ \\
\hline Morbidity & $\begin{array}{l}\text { Intraoperative } \\
\text { Immediate postoperative } \\
\text { Long-term postoperative }\end{array}$ \\
\hline $\begin{array}{l}\text { Prolonged } \\
\text { Unanticipat } \\
\text { Return hos } \\
\text { Patient satis } \\
\text { Postoperati }\end{array}$ & $\begin{array}{l}\text { aysion } \\
\text { ospital readmission }\end{array}$ \\
\hline
\end{tabular}

Deaths related to ambulatory surgery or anesthesia are extremely rare events, and very low rates of major morbidity are reported repeatedly throughout the relevant literature. Warner et al. following 38,598 ambulatory surgical patients for 30 days after surgery documented only four deaths, of which two were due to myocardial infarction, and two were the result of automobile accidents. ${ }^{1}$ In the same study, $31(0.08 \%)$ cases of major morbidity, including myocardial infarction, stroke, pulmonary embolism and respiratory failure, were reported among patients. Natof reported that no deaths occurred, and only 106 patients $(0.8 \%)$ had mainly surgical complications within two weeks after ambulatory surgery among 13,433 patients. ${ }^{2}$ Similarly, in three other prospective studies involving large numbers of ambulatory surgical patients, ranging from 6,000 to 17,638 , no perioperative deaths were identified..$^{3-5}$ The morbidity rates of the latter studies varied between $4 \%$ and $5 \%$ in the intraoperative period, and between $7 \%$ and $10 \%$ in the immediate postoperative period, during the patients' stay at the ambulatory surgical units. ${ }^{3-6}$ These studies, however, also include minor non-life threatening adverse events, such as blood pressure irregularities, postoperative pain, and postoperative nausea and vomiting (PONV).

The inclusion of not only major, but also less serious, adverse events as outcomes obviously results in higher morbidity rates, which allows better differentiation of the quality of care at different ambulatory surgical centres. It also reflects the burden of ambulatory surgery on health care providers and on patients more appropriately, since even minor events can necessitate extra patient care and can prevent the patients from returning to their preoperative functional level. Comparisons among different centres, however, should be made with caution. Characteristics of the patient population, type of the surgical procedure and the anesthetic technique could influence these morbidity rates. Also, how these non-life threatening adverse events are defined (e.g. what is the cut-off point for high blood pressure; whether it is the absolute value or the intraoperative change in blood pressure that is reported) is extremely important when

From the Department of Anaesthesia, Toronto Hospital, Western Division, University of Toronto, Toronto, Ontario, Canada.

Address correspondence to: Dr. Frances Chung, Department of Anaesthesia, Toronto Hospital, Western Division, 399 Bathurst St., Toronto, Ontario, Canada M5T 2S8. Phone: 416-603-5118; Fax: 416-603-6494; E-mail: fchung@torhosp.toronto.on.ca 
TABLE II Incidence of intraoperative adverse events by patient age (Data from the Ambulatory Surgical unit of The Toronto Hospital, Western Division.)

\begin{tabular}{llll}
\hline Adverse events & $\begin{array}{l}\text { Rate of events (\%) } \\
\text { Patients }<65 y r \\
(n=12,852)\end{array}$ & $\begin{array}{l}\text { Rate of epents (\%) } \\
\text { Patients 65 } \geq y r \\
(n=4,786)\end{array}$ & $\begin{array}{l}\text { Rate of events (\%) } \\
\text { Total } \\
(n=17,639)\end{array}$ \\
\hline Intraoperative & 2.6 & 7.5 & 4.0 \\
Cardiovascular & 1.4 & 7.0 & 2.9 \\
Hypertension & 0.4 & 4.9 & 1.6 \\
Hypotension & 0.4 & 0.5 & 0.4 \\
Bradycardia & 0.5 & 0.4 & 0.4 \\
Dysrhythmia & 0.1 & 1.0 & 0.3 \\
Tachycardia & 0.1 & 0.2 & 0.1 \\
Respiratory & 0.6 & 0.2 & 0.5 \\
Laryngospasm/stridor & 0.2 & $<0.1$ & 0.2 \\
Desaturation & 0.2 & 0.1 & 0.1 \\
Bronchospasm & & 0 & 0.1 \\
Apnea & 0.2 & 0.1 & $<0.1$ \\
Intubation related events & $<0.1$ & 0.2 & 0.3 \\
Difficult & 0.3 & & 0.2 \\
intubation & & 0.1 & 0.1 \\
Unplanned intubation & 0.2 & $<0.1$ & \\
\hline
\end{tabular}

TABLE III Incidence of postoperative adverse events by patients' age (Data from the Ambulatory Surgical unit of The Toronto Hospital, Western Division.)

\begin{tabular}{llll}
\hline Adverse events & $\begin{array}{l}\text { Rate of events }(\%) \\
\text { Patients }<65 \mathrm{yr}\end{array}$ & $\begin{array}{l}\text { Rate of events }(\%) \\
\text { Patients } 65 \geq \mathrm{yr}\end{array}$ & $\begin{array}{l}\text { Rate of events }(\%) \\
\text { Total } \\
(\mathrm{n}=17,638)\end{array}$ \\
Postanesthesia Care Unit & $(\mathrm{n}=12,852)$ & $(\mathrm{n}=4,786)$ & 9.6 \\
Excessive pain & 12.1 & 3.1 & 4.7 \\
Nausea, vomiting & 6.3 & 0.6 & 2.2 \\
Shivering/hypothermia & 2.7 & 0.7 & 0.9 \\
Drowsiness/sleepiness & 1.1 & 0.2 & 0.4 \\
Cardiovascular & 0.6 & 0.1 & 0.6 \\
Respiratory & 0.4 & 1.1 & 0.4 \\
Excessive bleeding & 0.4 & 0.3 & 0.1 \\
Ambulatory Surgical Unit & 0.1 & 0.1 & 7.9 \\
Nausea, vomiting & 9.5 & 3.4 & 3.9 \\
Excessive pain & 4.8 & 1.3 & 1.9 \\
Dizziness & 2.2 & 1.0 & 1.3 \\
Drowsiness & 1.7 & 0.4 & 0.3 \\
Cardiovascular & 0.4 & $<0.1$ & 0.1 \\
Excessive bleeding & 0.1 & 0.3 & 0.1 \\
\hline
\end{tabular}

estimating these rates, since they can be considerably altered by changing the definitions. The incidence of intraoperative and postoperative adverse events at our institution are listed in Tables II and III.

\section{Cardiovascular Adperse Events}

Cardiovascular adverse events are the most common intraoperative adverse events occurring during ambulatory surgery. ${ }^{3,5-7}$ Of these cardiovascular events, blood pressure abnormalities (hypertension and hypotension) occur most frequently. The incidence rates vary around $2 \%$ but in one Finnish study the authors reported hypotension in $16 \%$ of patients. ${ }^{3,5,7}$ The wide variation is probably the result of different definitions. The second most common events are rhythm disorders, such as bradycardia, tachycardia and arrhythmia that occur in 1$2 \%$ of ambulatory patients, although in the Finnish study the authors reported bradycardia in $14 \%$ of their patients. Cardiovascular events also occur in the immediate postoperative period but with much lower frequencies. 3,6 

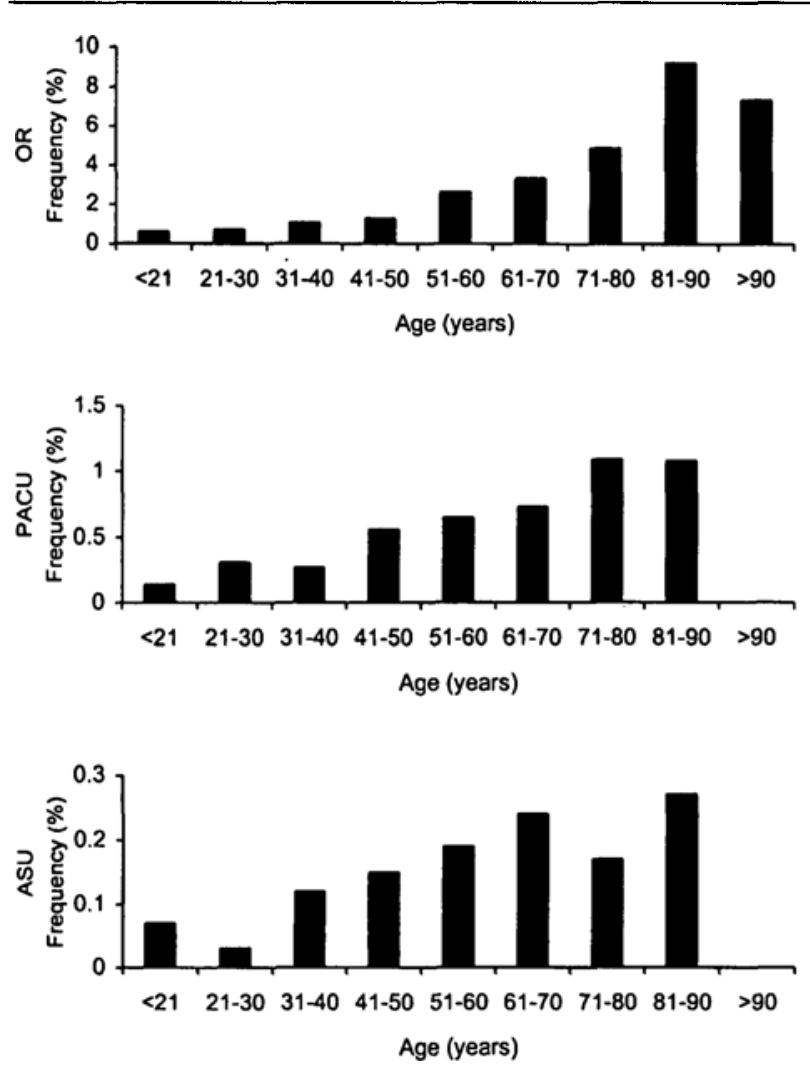

FIGURE 1 Frequency of intraoperative and postoperative cardiovascular adverse events by age group. (Data from the Ambulatory Surgical Unit of The Toronto Hospital, Western Division.)

Perioperative cardiovascular adverse events may result in considerably prolonged postoperative stay. ${ }^{8}$ Cardiovascular events warranting unanticipated hospital admissions are infrequent. Life-threatening cardiovascular adverse events, such as myocardial infarction, are extremely rare among ambulatory surgical patients. ${ }^{1,9}$ In fact, Warner et al. found that the incidence of severe cardiovascular complications is lower than the rate expected in the general population. ${ }^{1}$

Cardiovascular events occur with higher frequency among patients with preexisting cardiovascular diseases (e.g. hypertension, congestive heart failure). Increasing age is also associated with higher incidence of cardiovascular events (Figure 1), which could be explained by the higher frequency of preexisting cardiovascular conditions among elderly patients. ${ }^{3,6,10}$

\section{Respiratory Adverse Events}

Respiratory events are the second most frequent intraoperative adverse events occurring with a frequency of

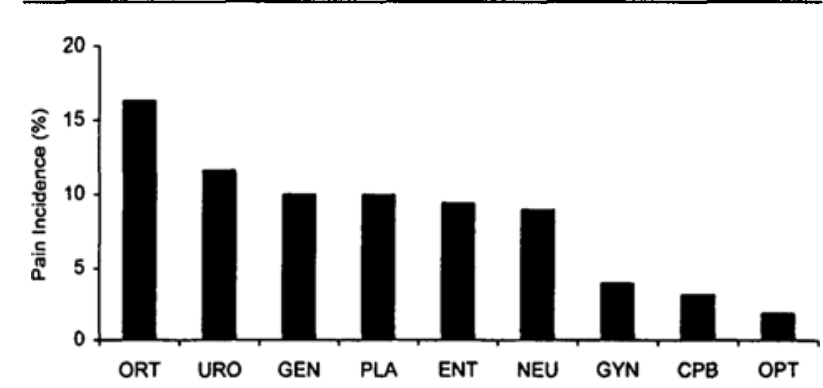

FIGURE 2 Incidence of postoperative severe pain by type of surgery $(\mathrm{ORT}=$ orthopedic, URO = urology, GEN = general surgery, PLA = plastic surgery, ENT = Ear, nose, throat and dental surgery, $\mathrm{NEU}=$ neurosurgery, $\mathrm{GYN}=$ gynecology, $\mathrm{CPB}=$ chronic pain block, OPT = ophthalmology) (Data from the Ambulatory Surgical Unit of The Toronto Hospital, Western Division.)

$<1 \%{ }^{3,5}$ The most common respiratory adverse events are laryngospasm and bronchospasm with or without desaturation but episodes of apnea, aspiration, pneumothorax, and pulmonary edema are also reported. ${ }^{2,3,5,11}$ Intubation related events during general anesthesia, such as difficult intubation, esophageal intubation or dental damage also occur with very low incidence $(0.2-0.5 \%)^{3,5}$ Although infrequent, respiratory events may result in unanticipated patient admission. 9,11

Patient characteristics are strongly associated with respiratory adverse events. Smokers, obese patients, and patients with asthma are at a 2-5-fold higher risk of developing intraoperative and postoperative respiratory events. ${ }^{3,10}$

\section{Postoperative Pain}

Postoperative pain is one of the most frequent postoperative adverse events occurring after ambulatory surgery. Surgical factors, such as type and invasiveness of surgery, have the most important effect on the incidence of severe postoperative pain (Figure 2). Patients undergoing certain orthopedic, urological and plastic surgical procedures can experience extremely high, $40-70 \%$ incidence of severe pain. ${ }^{12-14}$ In addition to the type of surgery, longer procedures are associated with a higher incidence of pain. ${ }^{12}$

Correct pain management is a corner stone of the efficiency of ambulatory surgical care. Severe and moderate postoperative pain decreases the patients' postoperative functional level to a considerable degree. ${ }^{15}$ Severe postoperative pain is associated with longer postoperative stay, higher rate of unanticipated admission and readmission. ${ }^{8,9,16,17}$ Pain also precipi- 
TABLE IV Postoperative symptoms $24 \mathrm{hr}$ after ambulatory surgery by telephone interview $(n=778)$

\begin{tabular}{ll}
\hline Symptoms & Frequency (\% of patients) \\
\hline Pain at surgical site & 26.9 \\
Headache & 11.6 \\
Drowsiness & 11.5 \\
Dizziness & 9.7 \\
Nausea, vomiting & 7.1 \\
Fever & 5.0 \\
\hline
\end{tabular}

tates PONV, which is another common postoperative symptom resulting in prolonged stay and hospital admission, underlining the importance of appropriate pain management in ambulatory surgery.

Appropriate pain management may extend throughout the preoperative, intraoperative and postoperative periods. Preoperative use of non-steroidal anti-inflammatory drugs may considerably decrease postoperative pain. ${ }^{18,19}$ The choice of anesthesia technique and drugs used during anesthesia, and the timing of the drugs given can also influence the frequency and severity of postoperative pain. Opioids are the most favoured drugs for postoperative pain management.

However, their use is limited because they provoke PONV. Multimodal analgesia, the simultaneous use of local anesthetics, non-steroidal anti-inflammatory and opioid drugs, is an effective alternative providing appropriate pain control without inducing PONV and facilitating the patients' quick but safe discharge. ${ }^{20}$

\section{Post Operative Nausea and Vomiting}

Postoperative nausea and vomiting (PONV) is an important and frequent complication related to ambulatory anesthesia. Although its incidence seems to be deceasing, probably as a result of the widespread use of newer anesthetic drugs and surgical techniques, it is still one of the strongest predictors of prolonged postoperative stay and unanticipated hospital admission. ${ }^{8,21,22}$ In addition, PONV is a very distressing symptom for patients, which strongly affects their postoperative functional level and their satisfaction with ambulatory surgery and anesthesia. ${ }^{15,23}$

The frequency of PONV shows wide variation by type and duration of anesthesia, the anesthetic drugs used, type of surgery and different patient characteristics. Of these factors, the type of anesthesia seems to have the most significant influence on the incidence of PONV. General anesthesia is associated with the high-
TABLE V Association between the presence of pre-existing medical condirions and adverse outcomes (Data from the Ambulatory Surgical Unit of The Toronto Hospital, Western Division.)

\begin{tabular}{|c|c|}
\hline Medical condition & Associated adperse outcome \\
\hline Congestive heart failure & $12 \%$ prolongation of postoperative stay \\
\hline Hypertension & $\begin{array}{l}\text { 2-fold increase in the risk of intraopera- } \\
\text { tive cardiovascular events }\end{array}$ \\
\hline Asthma & $\begin{array}{l}5 \text {-fold increase in the risk of postopera- } \\
\text { tive respiratory events }\end{array}$ \\
\hline Smoking & $\begin{array}{l}\text { 4-fold increase in the risk of postopera- } \\
\text { tive respiratory events }\end{array}$ \\
\hline Obesity & $\begin{array}{l}\text { 4-fold increase in risk of intraoperative } \\
\text { and postoperative respiratory events }\end{array}$ \\
\hline GE reflux & $\begin{array}{l}8 \text {-fold increase in the risk of intubation } \\
\text { related adverse events }\end{array}$ \\
\hline
\end{tabular}

est incidence, with an even higher frequency among patients receiving inhalation agents. ${ }^{21}$ The use of newer intravenous anesthetic agents, especially propofol, is associated with a lower frequency of PONV. The frequency of PONV also varies widely by type of surgery (Figure 3). Patient undergoing more painful procedures, such as certain ENT, urological, orthopedic and plastic surgical procedures (e.g. breast augmentation) have a higher risk. ${ }^{24}$ Among patient characteristics, female sex, younger age, obesity, history of motion sickness and history of previous PONV are risk factors for a high incidence of PONV. Smoking seems to decrease the incidence of PONV. ${ }^{3,21}$

PONV is strongly associated with pain and its management. More painful procedures are also associated with higher rate of PONV, and the most frequently used analgesics, opioids are potent emetics. Although antiemetic prevention is not used routinely at most ambulatory surgical centres, it is recommended in high-risk patients with multiple risk factors ${ }^{25}$

\section{Minor Sequelae}

Sore throat, shivering, dizziness, drowsiness and headache are among the frequently described and neglected minor complications, which could also result in prolonged postoperative stay, and strongly influence patient satisfaction and functional level (Table IV). ${ }^{14,15}$ Sore throat frequently occurs after intubation, or following the use of a laryngeal mask. Headache is a potential complication following spinal anesthesia, while dizziness and drowsiness may be prevented by adequate hydration. ${ }^{26}$ 


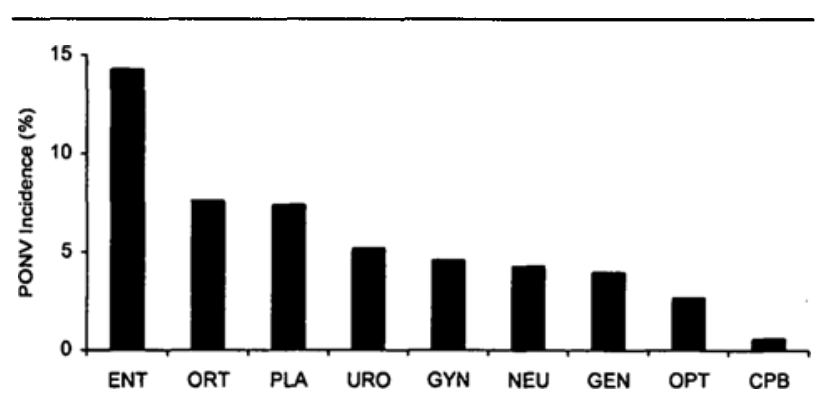

FIGURE 3 Incidence of postoperative nausea and vomiting (PONV) by type of surgery (ENT $=$ Ear, nose, throat and dental surgery, ORT = orthopedic, PLA = plastic surgery, URO = urology, GYN = gynecology, NEU = neurosurgery, GEN = general surgery, $\mathrm{OPT}=$ ophthalmology, $\mathrm{CPB}=$ chronic pain block) (Data from the Ambulatory Surgical Unit of The Toronto Hospital, Western Division.)

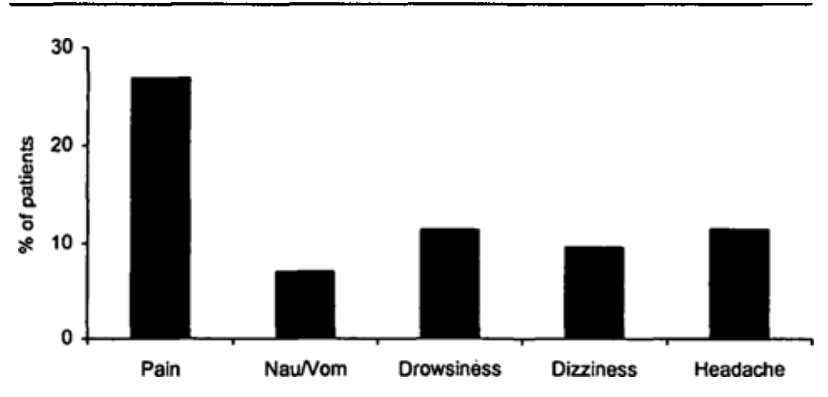

FIGURE 4 Postoperative symptoms $24 \mathrm{hr}$ after ambulatory surgery by telephone interview $(\mathrm{n}=778)$. Nau/Vom $=$ nausea/vomiting

\section{Elderly Patients and Patients with Preexisting Medical Conditions}

With the improvement in anesthetic and surgical techniques, ambulatory surgery becomes increasingly safer, which facilitates an ever-widening range of patients undergoing surgery in ambulatory settings. More elderly patients and patients with preexisting medical conditions opt for surgery as an outpatient.

The elderly patient population is the fastest growing segment of ambulatory surgical patients. One of the main advantages of ambulatory surgery is that it allows the patients to return to their regular environment and lifestyle with minimal disruption. This is particularly important among the elderly, who have decreased ability to adapt to new situations and change in environment. The elderly face a higher risk of developing intraoperative and postoperative cardiovascular events than do younger patients, but elderly

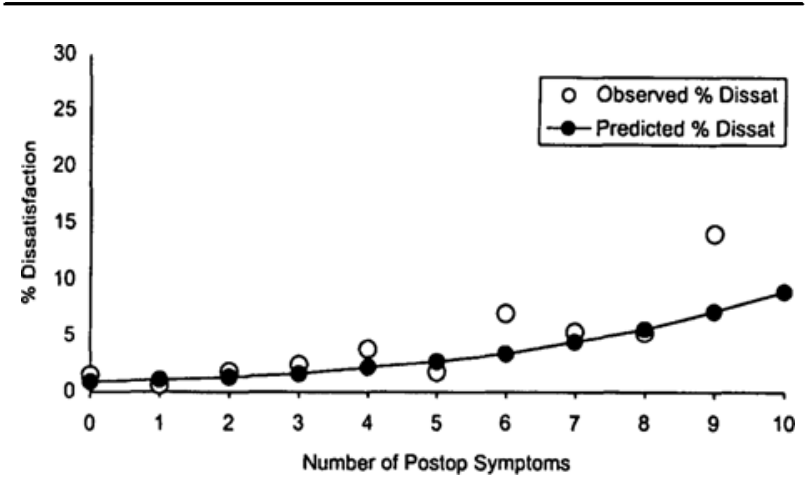

FIGURE 5 Predicted (solid circles) and observed (open circles) dissatisfaction with anesthesia based on number of postoperative symptoms.

patients are less likely to suffer from all other intraoperative and postoperative events, such as excessive pain, PONV, drowsiness and dizziness. ${ }^{6}$ The two-fold increase in the risk of cardiovascular events among the elderly does not contraindicate ambulatory surgery, but underlines the importance of appropriate perioperative cardiovascular management of elderly patients.

Certain preexisting medical conditions also increase the risk of intraoperative and postoperative adverse events (Table V). Patients with congestive heart failure experience prolonged postoperative stay and patients with hypertension have higher risk of cardiovascular events. Smokers and obese patients, and patients with asthma have higher risk of respiratory events, and obesity increases the likelihood of PONV, while smokers are less likely to suffer PONV. ${ }^{3,10}$ These associations, while they do not preclude patients from undergoing ambulatory surgery, warn anesthesiologists that the anesthetic care of each patient needs to be individualized based on the patient's characteristics.

\section{Prolonged Postoperative Stay}

Duration of postoperative stay or time to discharge is a commonly used outcome measure of ambulatory surgery and anesthesia. ${ }^{27-29}$ It is considered to be an intermediate or surrogate measure for the 'real' outcomes, such as patient recovery. Although it is a surrogate for recovery, it is also one of the 'real' outcomes, since length of postoperative stay of the whole patient population has a direct influence on the cost of operating postanesthesia care units.

Duration of postoperative stay correlates with the frequency of minor or moderately severe complications. Although these complications usually do not necessitate 
hospital admission, they can delay patient discharge considerably. Quick recovery with speedy discharge signifies success, while prolonged postoperative stay reflects failure, because it could result in increased cost. Although this measure is simple and straightforward, one should be circumspect with its use.

Actual discharge time may be very different from the time when the patient is ready for discharge. While actual discharge time has more influence on the cost of postanesthesia care, the time to reach home-readiness reflects the pace of patient recovery. The cause of the discrepancy between the two times could be late or unavailable escort, or inadequate or inefficient discharge practices. ${ }^{23}$ It is important to emphasize that discharge time needs to be individualized and patients can be discharged safely once they fulfill the discharge criteria.

In order to accelerate safe discharge it is imperative to establish appropriate discharge criteria. ${ }^{30-32}$ In addition to ensuring that the patient has stable vital signs, is oriented and does not have debilitating PONV, excessive pain, or bleeding, and that a responsible escort is available, the patient should be able to ambulate, void, and tolerate oral fluids. However, the requirement for drinking and voiding are strongly debated, since studies showed that patients could be discharged without problems before fulfilling these criteria. ${ }^{33,34}$

With the use of fast acting anesthetics and minimally invasive surgical techniques, many ambulatory surgical patients can be discharged safely within one or two hours, and most within three hours. ${ }^{3,8,32,35}$ In one study $82 \%$, and in another study $54 \%$ of the patients were discharged within two hours. In a simulation study it was demonstrated that only a large decrease in the mean duration of postoperative stay would result in cost savings to postanesthesia care units: the cost was more sensitive to the peak number of concurrent patients. ${ }^{36}$ To reduce this peak with optimal scheduling and appropriately individual patients postoperative management, it is relevant to know what surgical, anesthetic, or patient related factors are associated with prolonged postoperative stay.

The length of postoperative stay and the occurrence of prolonged postoperative stay are most influenced by the type of anesthesia and surgery. ${ }^{8,37}$ General anesthesia, which is associated with a high incidence of PONV (10\%-50\%), and certain ENT, orthopedic and urologic procedures, which are frequently more painful than other surgical procedures, are associated with lengthy stay. ${ }^{12,13,22,24}$ Excessive pain and PONV increase stay 3 to 4 -fold. ${ }^{8,12}$ Both complications occur in large proportion of the patients. Other adverse events, such as cardiovascular events, drowsiness and dizziness may also lengthen stay. ${ }^{8}$ However, these events occur in fewer patients and produce less impact on the whole ambulatory surgical population. ${ }^{6}$

Patient characteristics, such as sex and age, are associated with adverse events. Women are more prone to suffer from PONV than are men. ${ }^{21}$ Younger patients are more likely to suffer from excessive pain and PONV, while the elderly are more likely to experience cardiovascular adverse events. ${ }^{6}$

\section{Unanticipated Hospital Admission}

Safe discharge after surgery is an essential part of ambulatory surgical care. Unplanned inpatient hospital admission represent an extra burden of ambulatory surgery on the health care system. More appropriately, the gains obtained by performing the surgery on an outpatient basis are lost.

Similar to prolonged postoperative stay, the rate of unanticipated or unplanned hospital admissions following ambulatory surgery reflects the occurrence of intraoperative or postoperative complications in the immediate postoperative period. Unanticipated hospital admission rates, however, usually mirror the frequency of severe complications, which prevent safe discharge after surgery and necessitate inpatient care. The rates of unanticipated admissions range between $0.3 \%$ and $1.4 \% .4,9,11,13,16,35$

The most frequent reasons for unanticipated hospital admission (38-79\%) are surgical complications. ${ }^{4,9,11,16}$ Among these, excessive pain, bleeding, and surgical misadventure are the most frequent. Anesthesia related complications, most frequently PONV, somnolence or dizziness and, less frequently, aspiration, are the reasons for admissions in 10-26\% of unanticipated hospital admissions. ${ }^{4,9,11,16}$ In $6-17 \%$ of cases, the patients are admitted for medical reasons. These medical admissions occur either because of presence or worsening of preexisting medical conditions, such as diabetes, angina, and sleep apnea, or as a result of intraoperative or postoperative complications, such as dysrhythmia, myocardial

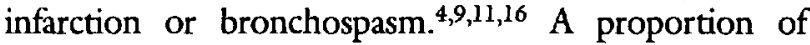
unanticipated hospital admissions (5-20\%) occur for social reasons, such as no available escort or inadequate home support. $4,9,16$

Patients undergoing painful surgery, such as ENT, urological and orthopedic procedures, are about 430 -fold more likely to be admitted following surgery. ${ }^{9}$ Type and duration of anesthesia are also predictors of unanticipated hospital admission. Patients receiving general anesthesia are 2 -5-fold more likely to be admitted than are patients without general anesthesia. The probability of admission increases with longer anesthesia ${ }^{9,11}$ Patients, whose surgery ends late during the day, are more likely to be admitted. ${ }^{9}$ 


\section{Return Hospital Visits and Readmission}

The impact of ambulatory surgery on patients and on health care providers continues after safe same day discharge. Complications may develop or recur during at home. Therefore, to assess the overall safety of ambulatory surgery, and its burden on health care, it is essential to extend the investigation into after discharge, investigating further need for medical care.

Questionnaire or phone interview based studies may include information on any patient/physician contact. Most of the patient-visits to doctors' offices, however, are due to minor problems or for postoperative followup. Postoperative returns to emergency departments and hospital readmission following discharge signify more serious events. Studies involving ambulatory surgical patients traditionally follow the patients for 24-72 hr following discharge, during which complications are most likely to develop. ${ }^{4,14,35,38}$ However, to capture all relevant postoperative events and to obtain a full picture on ambulatory surgery related hospital returns and readmission, a longer follow-up, for at least 30 days, is required.

Published results show that within the first 24-72 hr 4-8\% of ambulatory surgical patients are seen by a doctor, while this proportion may increase to $12 \%$ within the first postoperative month., $4,35,38$ Hospital readmission rates are lower, $0-3 \%$, within one month of ambulatory surgery. ${ }^{13,17,35,39}$ In the latest and most comprehensive published study on hospital readmission following ambulatory surgery, Twersky et al. found that, although $3 \%$ of their 6,243 patients were admitted to hospital within one month of discharge, only $1.3 \%$ of patients were admitted as a result of complications. ${ }^{17}$ The most common reasons for complication-related readmission were bleeding, fever and infection, pain, wound disruption, and urinary retention. Twersky $e t a l$. also found that patients undergoing urological procedures were the most likely to be readmitted to hospital. ${ }^{17}$ They argue that this group of patients is inherently vulnerable, since they are prone to demonstrate symptoms, such as hematuria, infection, and urinary retention, symptoms which usually result in hospital admission.

At our institution, we found that during a three year period only $1.1 \%$ of 17,638 patients were readmitted within 30 days of ambulatory surgery, and only $13 \%$ of these were due to surgical or medical complications. Neither study was able to identify any anesthesia related readmissions.

\section{Patient Satisfaction}

Although patient satisfaction is a subjective measure of patient care, it is important, since it affects other health care outcomes and the use of health care services. ${ }^{23}$ Patient satisfaction with ambulatory surgery and anesthesia is generally high, $97-99 \%$ of patients are satisfied with their ambulatory care. ${ }^{13,23,35}$ The main reasons for dissatisfaction with anesthesia are intraoperative and postoperative adverse events (e.g. inadequate anesthesia during monitored anesthesia care, PONV, sore throat). ${ }^{23}$ Dissatisfaction is also strongly associated with the number of symptoms the patients develop. ${ }^{23}$

\section{Postoperative Functional Level}

Complete return of patients to their preoperative (or pre-illness) functional level represents the ultimate success of ambulatory surgery and anesthesia. However, after ambulatory surgery, postoperative functional level is decreased ${ }^{14,15,40}$ associated with the presence or absence of postoperative symptoms. ${ }^{14}$ The presence of severe or moderate postoperative pain and PONV causes the largest decrease in functional level $24 \mathrm{hr}$ after surgery $\left(21 \%, 9 \%\right.$ and $7 \%$, respectively). ${ }^{15}$ Swan $e t a l$. showed that ambulatory surgical patients experienced decreased functional status during the first seven postoperative days and only $22 \%$ of the patients returned to full- or part-time work by the seventh day after operation. ${ }^{40}$ These findings suggest that, although the provider 'cost' may have been reduced with the transition from inpatient care to ambulatory surgery, a large portion of the cost or impact of the patient care may merely have been shifted to the patient or the patient's family.

\section{Conclusion}

Ambulatory surgery, as currently practiced, has an excellent safety record. Major morbidity is infrequent, and death is extremely rare during or following ambulatory surgical procedures. Less serious, non lifethreatening perioperative adverse events, such as intraoperative cardiovascular events and, most frequently, postoperative excessive pain and PONV, occur with higher incidence. These minor adverse events could result in prolonged postoperative stay, unanticipated hospital admission, or hospital readmission, and they also affect patient satisfaction and postoperative functional level. The occurrence of these minor adverse events is now the major area of quality assessment and an area where improvement could be targeted. The goal of reducing the incidence of minor adverse events related to ambulatory surgery could be achieved by development of less invasive surgical techniques, the use of newer shorter acting anesthetic drugs with fewer side effects, and improved postoperative pain management. 


\section{References}

1 Warner MA, Sbields SE, Chute CG. Major morbidity and mortality within 1 month of ambulatory surgery and anesthesia. JAMA 1993; 270: 1437-41.

2 Natof HE. Complications associated with ambulatory surgery. JAMA 1980; 244: 1116-8.

3 Duncan PG, Coben MM, Tweed WA, et al. The Canadian four-centre study of anaesthetic outcomes: III. Are anaesthetic complications predictable in day surgical practice? Can J Anaesth 1992; 39: 440-8.

4 Osborne $G A$, Rudkin GE. Outcome after day-care surgery in a major teaching hospital. Anaesth Intensive Care 1993; 21: 822-7.

5 Chung F, Mezei G. Intraoperative adverse events during ambulatory surgical procedures. Can J Anaesth 1997; 44: A70A.

6 Chung F, Mezei $G$, Tong D. Adverse events in ambulatory surgery: a closer look at the elderly. Anesthesiology 1997; 87: A40.

7 Heino A, Vainio J, Turunen M, Labtinen J. Results of 500 general surgery patients operated on in the ambulatory surgical unit. Ann Chir Gynaecol 1992; 81: 295-9.

8 Chung F, Mezei $G$. What are the factors causing prolonged stay after ambulatory anesthesia? Anesthesiology 1998; 89: A3.

9 Fortier J, Chung F, Su J. Unanticipated admission after ambulatory surgery - a prospective study. Can J Anaesth 1998; 45: 612-9.

10 Chung F, Mezei G, Tong D. Preexisting medical conditions as predictors of adverse events in ambulatory surgery. Anesthesiology 1997; 87: A27.

11 Gold BS, Kitz DS, Lecky JH, Neubaus JM. Unanticipated admission to the hospital following ambulatory surgery. JAMA 1989; 262: 3008-10.

12 Chung F, Ritchie E, Su J. Postoperative pain in ambulatory surgery. Anesth Analg 1997; 85: 808-16.

13 Cardosa $M, R u d k i n$ GE, Osborne GA. Outcome from day-case knee arthroscopy in a major teaching hospital. Arthroscopy 1994; 10: 624-9.

14 Chung F, Un V, Su J. Postoperative symptoms 24 hours after ambulatory anaesthesia. Can J Anaesth 1996; 43: 1121-7.

15 Tong D, Chung F, Mezei G. Which specific postoperative symptoms predict postoperative functional level in ambulatory patients? Anesthesiology 1997; 87: A37.

16 Fancourt-Smith PF, Hornstein J, Jenkins LC. Hospital admissions from the surgical day care centre of Vancouver General Hospital 1977-1987. Can J Anaesth 1990; 37: 699-704.

17 Twersky $R$, Fishman D, Homel P. What happens after discharge? Return hospital visits after ambulatory surgery. Anesth Analg 1997; 84: 319-24.
18 Ding $\Upsilon$, White PF. Comparative effects of ketorolac, dezocine and fentanyl as adjuvants during outpatient anesthesia. Anesth Analg 1992; 75: 566-71.

19 Comfort VK, Code WE, Rooney ME, Yip RW. Naproxen premedication reduces postoperative tubal ligation pain. Can J Anaesth 1992; 39: 349-52.

20 Michaloliakou C, Chung F, Sharma S. Preoperative multimodal analgesia facilitates recovery after ambulatory laparoscopic cholecystectomy. Anesth Analg 1996; 82: 44-51.

21 Watcha $M F$, White PF. Postoperative nausea and vomiting. Its etiology, treatment and prevention. Anesthesiology 1992; 77: 162-84.

22 Green $G$, Jonsson $L$. Nausea: the most important factor determining length of stay after ambulatory anaesthesia. A comparative study of isoflurane and/or propofol techniques. Acta Anaesthesiol Scand 1993; 37: 742-6.

23 Tong $D$, Chung $F$, Wong $D$. Predictive factors in global and anesthesia satisfaction in ambulatory surgical patients. Anesthesiology 1997; 87: 856-64.

24 Sinclair D, Chung F, Mezei G. Relation of postoperative nausea and vomiting to the surgical procedure. Can J Anaesth 1998; 45: A25A.

25 Khalil SN, Kataria $B$, Pearson $K$, et al. Ondansetron prevents postoperative nausea and vomiting in women outpatients. Anesth Analg 1994; 79: 845-51.

26 Yogendran S, Asokumar B, Cheng DCH, Chung F. A prospective randomized double-blinded study of the effect of intravenous fluid therapy on adverse outcomes on outpatient surgery. Anesth Analg 1995; 80: 682-6.

27 Raeder J, Gupta A, Pedersen FM. Recovery characteristics of sevoflurane- or propofol-based anaesthesia for day-care surgery. Acta Anaesthesiol Scand 1997; 41 : 988-94.

28 Richardson $M G, W u C L$, Hussain A. Midazolam premedication increases sedation but does not prolong discharge times after brief outpatient general anesthesia for laparoscopic tubal sterilization. Aneth Analg 1997; 85: 301-5.

29 Davis PJ, McGowan FX, Landsman I, Maloney $K$, Hoffmann $P$. Effect of antiemetic therapy on recovery and hospital discharge time. Anesthesiology 1995; 83: 956-60.

30 Chung F, Chan VWS, Ong D. A post-anesthetic discharge scoring system for home readiness after ambulatory surgery. J Clin Anesth 1995; 7: 500-6.

31 Korttila $K$. Recovery from outpatient anaesthesia. Factors affecting outcome. Anaesthesia 1995; 50(Suppl): 22-8.

32 Chung $F$. Recovery pattern and home-readiness after ambulatory surgery. Anesth Analg 1995; 80: 896-902.

33 Jin $F$, Norris $A$, Cbung $F$, Ganeshram $T$. Should adult patients drink fluids before discharge from ambulatory surgery? Anesth Analg 1998; 87: 306-11. 
34 Fritz WT, George L, Krull N, Krug J. Utilization of a home nursing protocol allows ambulatory surgery patients to be discharged prior voiding. (Abstract) Anesth Analg 1997; 84: S6.

35 Cbye EPY, Young IG, Osborne GA, Rudkin GE. Outcome after same-day oral surgery: a review of 1,180 cases at a major teaching hospital. J Oral Maxillofac Surg 1993; 51: 846-9.

36 Dexter F, Tinker JH. Analysis of strategies to decrease postanesthesia care unit costs. Anesthesiology 1995; 82: 94-101.

37 Pavlin DJ, Rapp SE, Polissar NL, Malmgren JA, Koerschgen $M$, Keyes $H$. Factors affecting discharge time in adult outpatients. Anesth Analg 1998; 87: 816-26.

38 Ghosh $S$, Sallam S. Patient satisfaction and postoperative demands on hospital and community services after day surgery. Br J Surg 1994; 81: 1635-8.

39 Henderson J, Goldacre MJ, Griffith $M$, Simmons $H M$. Day case surgery: geographical variation, trends and readmission rates. J Epidemiol Community Health 1989; 43: 301-5.

40 Swan BA, Maislin G, Traber KB. Symptom distress and functional status shanges during the first seven days after ambulatory surgery. Anesth Analg 1998; 86: $739-45$. 
Frances Chung MD FRCPC, Gabor Mezei MD PhD

\section{Les complications de l'anesthésie ambulatoire}

$\mathrm{P}$ ENDANT les deux dernières décennies, les soins chirurgicaux ont subi des changements majeurs. Pendant que dans le passé, la plupart des interventions chirurgicales nécessitaient l'hospitalisation du patient, presque toutes les opérations, une estimation de $65 \%$ en Amérique du Nord, sont maintenant réalisées dans le cadre ambulatoire. L'amélioration des techniques anesthésiques et chirurgicales, qui a conduit à un bilan très positif sur la sécurité des interventions ambulatoires, était un prérequis à l'accroissement radical du nombre d'opérations pratiquées dans les unités de chirurgie ambulatoirc. Le but de notre mise à jour est d'examiner quelles sont les mesures utiles à l'évaluation de la sécurité de la chirurgie ambulatoire et de résumer les résultats disponibles concernant ces mesures (Table I).

\section{Mortalité et morbidite}

Les mesures habituelles de la qualité et de la sécurité de la chirurgie et de l'anesthésie sont les taux de mortalité et de morbidité périopératoires. Ces mesures sont facilement applicables à la chirurgie et à l'anesthésie ambulatoires. Cependant, les taux de mortalité et de morbidité ne sont que des mesures approximatives qui ne reflètent pas nécessairement la qualité des soins, mais plutôt l'état de santé global des patients qui subissent une intervention ambulatoire, qualité qui pourrait différer d'un centre chirurgical à l'autre. Qui plus est, la rareté des incidents négatifs en chirurgie ambulatoire, qui prouve la sécurité de cette pratique, en limite l'utilisation dans l'évaluation de la qualité.

La mortalité liée à la chirurgie ou à l'anesthésie ambulatoire est extrêmement rare et de très faibles taux de morbidité majeure sont rapportés régulièrement dans la littérature sur le sujet. Warner et coll., qui ont suivi 38598 patients de chirurgie ambulatoire pendant 30 jours après l'intervention, n'ont constaté que quatre décès dont deux étaient survenus à la suite d'un infarctus myocardique et deux lors d'accidents de la route. ${ }^{1}$ L'étude fait aussi état de $31(0,08 \%)$ cas de morbidité majeure comprenant l'infarctus myocardique, l'accident vasculaire cérébral, l'embolie pulmonaire et l'insuffisance respiratoire. Natof, quant à lui, ne rapporte aucun décès et seulement 106 patients $(0,8 \%)$, sur 13433 , ont présenté des complications chirurgicales principalement pendant les deux semaines qui ont suivi l'opération..$^{2}$ De même, trois autres études prospectives portant sur un grand nombre de patients en chirurgie ambulatoire, de 6000 à 17638 , ne signalent aucun décès périopératoire. ${ }^{3-5}$ Les taux de morbidité de ces dernières études varient de $4 \%$ à $5 \%$ pendant l'intervention, et de $7 \%$ à $10 \%$ immédiatement après, pendant le séjour du patient à l'unité de chirurgie ambulatoire. ${ }^{3-6}$ Par ailleurs, ces études tiennent compte de complications mineures, sans danger pour la vie du patient, comme les irrégularités de tension artérielle, les douleurs postopératoires et les nausées et vomissements postopératoires (NVPO).

Le fait d'inclure non seulement les complications majeures mais aussi les moins importantes dans les résultats, crée évidemment un taux de morbidité plus élevé qui permet une meilleure différenciation de la qualité des soins entre les centres ambulatoires chirurgicaux. Elle reflète également la charge de cette chirurgie ambulatoire sur les intervenants et les patients de façon plus adéquate, puisque même les incidents mineurs peuvent exiger des soins supplémentaires et empêcher les patients de retrouver leur niveau fonctionnel préopératoire. Les comparaisons entre centres doivent toutefois être faites avec prudence. Les caractéristiques de la population de patients, le type de chirurgie et de technique anesthésique peuvent influencer la morbidité. De plus, la définition de ces complications mineures (par ex. quel est le seuil discriminatif d'une haute tension artérielle; est-ce la valeur absolue ou le changement

TABLEAU I Mesures des résultats de l'anesthésie ambulatoire

\begin{tabular}{|c|c|}
\hline Mortalité & $\begin{array}{l}\text { Immédiate } \\
\text { Long terme }\end{array}$ \\
\hline Morbidité & $\begin{array}{l}\text { Peropératoire } \\
\text { Postopératoire immédiate } \\
\text { Postopératoire à long terme }\end{array}$ \\
\hline \multicolumn{2}{|c|}{ Séjour postopératoire prolongé } \\
\hline \multicolumn{2}{|c|}{ Hospitalisation non prévue } \\
\hline \multicolumn{2}{|c|}{ Retour à l'hôpital et réadmission } \\
\hline \multicolumn{2}{|c|}{ Satisfaction du patient } \\
\hline \multicolumn{2}{|c|}{ Niveau fonctionnel postopératoire } \\
\hline
\end{tabular}


TABLE II Incidence de complications peropératoires selon l'âge du patient (Données de l'Ambulatory Surgical unit of The Toronto Hospital, Western Division.)

\begin{tabular}{llll}
\hline Complications & $\begin{array}{l}\text { Taux (\%) } \\
\text { Patients }<65 \text { ans } \\
(n=12852)\end{array}$ & $\begin{array}{l}\text { Taux (\%) } \\
\text { Patients 65 }{ }^{3} \text { ans } \\
(n=4786)\end{array}$ & $\begin{array}{l}\text { Taux (\%) } \\
\text { Total } \\
(n=17639)\end{array}$ \\
\hline Peroperatoires & 2,6 & 7,5 & 4,0 \\
Cardiovasculaires & 1,4 & 7,0 & 2,9 \\
Hypertension & 0,4 & 4,9 & 1,6 \\
Hypotension & 0,4 & 0,5 & 0,4 \\
Bradycardie & 0,5 & 0,4 & 0,4 \\
Dysrythmie & 0,1 & 1,0 & 0,3 \\
Tachycardie & 0,1 & 0,2 & 0,1 \\
Respiratoires & 0,6 & 0,2 & 0,5 \\
Laryngospasme/stridor & 0,2 & $<0,1$ & 0,2 \\
Désaturation & 0,2 & 0,1 & 0,1 \\
Bronchospasme & 0,2 & 0 & 0,1 \\
Apnée & $<0,1$ & 0,1 & $<0,1$ \\
Liées à l'intubation & 0,3 & 0,2 & 0,3 \\
Intubation difficile & 0,2 & 0,1 & 0,2 \\
Intubation non prévue & 0,1 & $<0,1$ & 0,1 \\
\hline
\end{tabular}

TABLE III Incidence de complications postopératoires selon l'âge du patient (Données de l'Ambulatory Surgical unit of The Toronto Hospital, Western Division).

\begin{tabular}{llll}
\hline Complications & $\begin{array}{l}\text { Taux (\%) } \\
\text { Patients }<65 \text { ans } \\
(n=12852)\end{array}$ & $\begin{array}{l}\text { Taux (\%) } \\
\text { Patients 65 } 5^{3} \text { ans } \\
(n=4786)\end{array}$ & $\begin{array}{l}\text { Taux (\%) } \\
\text { Total } \\
(n=17638)\end{array}$ \\
\hline Salle de réveil & $\mathbf{1 2 , 1}$ & 3,1 & 9,6 \\
Douleurs intenses & 6,3 & 0,6 & 4,7 \\
Nausées, vomissements & 2,7 & 0,7 & 2,2 \\
Frissons/hypothermic & 1,1 & 0,2 & 0,9 \\
Étourdis/somnolence & 0,6 & 0,1 & 0,4 \\
Cardiovasculaires & 0,4 & 1,1 & 0,6 \\
Respiratoires & 0,4 & 0,3 & 0,4 \\
Saignements excessifs & 0,1 & 0,1 & 0,1 \\
Chirurgie ambulatoire & 9,5 & 3,4 & 7,9 \\
Nausées, vomissements & 4,8 & 1,3 & 3,9 \\
Douleurs intenses & 2,2 & 1,0 & 1,9 \\
Étourdissements & 1,7 & 0,4 & 1,3 \\
Somnolence & 0,4 & $<0,1$ & 0,3 \\
Cardiovasculaires & 0,1 & 0,3 & 0,1 \\
Saignements excessifs & 0,1 & 0,1 & 0,1 \\
\hline
\end{tabular}

peropératoire qui est rapporté) est très importante quand on évalue les risques, puisque ces derniers varient selon les définitions qu'on en donne. L'incidence des complications peropératoires et postopératoires observées dans notre institution se retrouvent aux Table II et III.

\section{Complications cardio-pasculaires}

Les complications cardio-vasculaires peropératoires sont les plus fréquentes à se produire pendant les interventions ambulatoires. ${ }^{3,5-7}$ Parmi elles, les ano- malies de la tension artérielle (hypertension et hypotension) se produisent le plus souvent. Leur incidence se situe autour de $2 \%$, mais une étude finlandaise rapporte un taux de $16 \%$ d'hypotension. $3,5,7$ La grande variation relève probablement de définitions différentes. Au deuxième rang des complications, les désordres du rythme comme la bradycardie, la tachycardie et l'arythmie se produisent chez 1-2\% des patients ambulatoires, quoique l'étude finlandaise indique $14 \%$ de bradycardie chez leurs patients. Les complications cardio-vasculaires surviennent aussi 

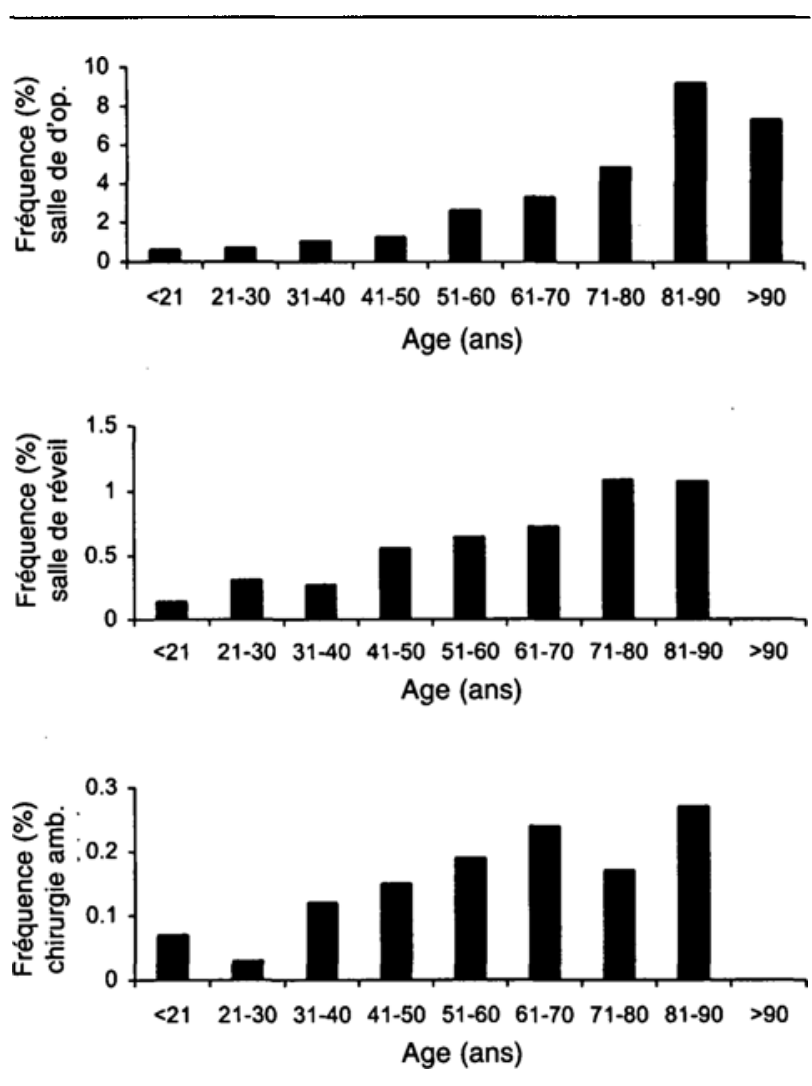

FIGURE 1 Fréquence des complications cardio-vasculaires peropératoires et postopératoires par groupe d'âges. (Données de l'Ambulatory Surgical Unit of The Toronto Hospital, Western Division.)

immédiatement après l'intervention mais elles sont beaucoup moins fréquentes. 3,6

Les complications cardio-vasculaires périopératoires peuvent être à l'origine d'une importante prolongation du séjour postopératoire à l'unité de soins. ${ }^{8}$ Les problèmes cardio-vasculaires justifiant une hospitalisation non prévue sont rares et les complications graves, comme l'infarctus du myocarde, sont très rares chez les patients de chirurgie ambulatoire. ${ }^{1,9}$ De fait, Warner et coll. ont découvert que l'incidence de complications cardio- vasculaires sévères est plus faible que le taux présumé dans la population générale. ${ }^{1}$

Ces complications sont plus fréquentes chez les patients qui ont déjà des maladies cardio-vasculaires (hypertension, insuffisance cardiaque congestive). L'âge est aussi associé à une plus forte incidence de ces complications (Figure 1), ce qui peut s'expliquer par la fréquence plus élevée de désordres cardio-vasculaires de longue date chez les gens âgés ${ }^{3,6,10}$

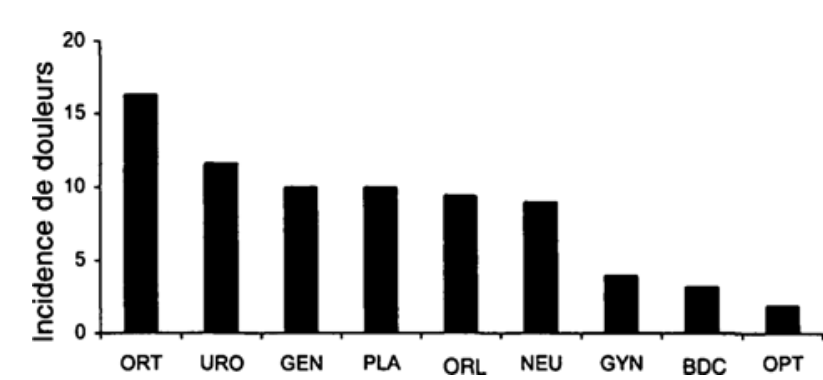

FIGURE 2 Incidence de douleurs sévères postopératoires selon le type de chirurgic (ORT = orthopédie, URO = urologie, GEN = chirurgie générale, PLA = plastie, ORL = oto-rhino-laryngologie et chirurgie dentaire, NEU = neurochirurgie, $\mathrm{GYN}=$ gynécologie, $\mathrm{BDC}=$ bloc pour douleurs chroniques, $\mathrm{OPT}=$ ophtalmologie $)$ (Données de l'Ambulatory Surgical Unit of The Toronto Hospital, Western Division.)

\section{Complications respiratoires}

Deuxièmes en importance parmi les complications peropératoires, les problèmes respiratoires présentent une fréquence $<1 \%{ }^{3,5}$ Les plus courants sont le laryngospasme et le bronchospasme avec ou sans désaturation, mais on rapporte aussi des épisodes d'apnée, d'aspiration, de pneumothorax et d'oedème pulmonaire. ${ }^{2,3,5,11}$ Des complications liées à l'intubation pendant l'anesthésie générale, comme l'intubation difficile, l'intubation oesophagienne ou des dommages dentaires, présentent également une très faible incidence $(0,2-0,5 \%) .3,5$ Bien que rares, les complications respiratoires peuvent amener une hospitalisation imprévue. 9,11

Les caractéristiques du patient sont fortement associées aux complications respiratoires. Les fumeurs, les patients obèses et les asthmatiques sont de 2 à 5 fois plus à risque de développer des complications respiratoires peropératoires et postopératoires. ${ }^{3,10}$

\section{Douleur postopératoire}

Les douleurs postopératoires sont l'une des complications les plus fréquentes à survenir après une intervention chirurgicale ambulatoire. Les facteurs chirurgicaux, comme le type de chirurgie et le caractère effractif de l'intervention, influencent davantage l'incidence de douleurs sévères postopératoires (Figure 2). Les patients qui subissent certaines interventions orthopédiques, urologiques et de chirurgie plastique peuvent présenter des taux de douleurs sévères extrêmement élevés, de 40 à $70 \% .{ }^{12-14} \mathrm{La}$ longueur des interventions est aussi associée à une plus grande incidence de douleurs. ${ }^{12}$ 
TABLE IV Symptômes postopératoires $24 \mathrm{~h}$ après la chirurgie ambulatoire selon l'interview téléphonique $(n=778)$

\begin{tabular}{ll}
\hline Symptómes & Fréquence (\% de patients) \\
\hline Douleur au site chirurgical & 26,9 \\
Céphalées & 11,6 \\
Somnolence & 11,5 \\
Étourdissements & 9,7 \\
Nausées, vomissements & 7,1 \\
Fièvre & 5,0 \\
\hline
\end{tabular}

Le traitement adéquat de la douleur est la pierre angulaire de l'efficacité des soins ambulatoires chirurgicaux. Les douleurs postopératoires sévères et modérées affectent le niveau fonctionnel du patient de manière considérable. ${ }^{15}$ Les douleurs postopératoires sévères sont associées à un séjour postopératoire prolongé, à un taux plus élevé d'hospitalisation et de réadmission imprévues. ${ }^{8,9,16,17}$ Les douleurs provoquent aussi les NVPO qui sont d'autres symptômes postopératoires fréquents ayant pour résultat un séjour prolongé et une hospitalisation, ce qui souligne l'importance du traitement adéquat des douleurs en chirurgie ambulatoire.

Le traitement de la douleur devrait s'étendre aux périodes préopératoire, peropératoire et postopératoire. L'usage préopératoire de médicaments anti-inflammatoires non stérö̈diens peut réduire considérablement les douleurs postopératoires. ${ }^{18,19}$ Le choix de la technique anesthésique et des médicaments utilisés pendant l'intervention, de même que le moment où les médicaments sont administrés peuvent aussi influencer la fréquence et la sévérité des douleurs postopératoires. Les opioides constituent le choix le plus fréquent pour le traitement de la douleur postopératoire.

Cependant, leur emploi est limité parce qu'ils entraînent des NVPO. L'analgésie multimodale, l'emploi simultané d'anesthésiques locaux, d'anti-inflammatoires non stéroïdiens et d'opioïdes, est une méthode efficace de contrôle des douleurs sans provoquer de NVPO tout en facilitant le retour rapide, mais sécuritaire, du patient à domicile. ${ }^{20}$

\section{Nausées et vomissements postopératoires}

Les nausées et vomissements postopératoires (NVPO) sont des complications importantes et fréquentes de l'anesthésie ambulatoire. Même si leur incidence tend à diminuer, sans doute à cause de l'usage répandu de nouveaux anesthésiques et techniques chirurgicales, ce sont les complications qui permettent le mieux de prédire un séjour postopératoire prolongé et une hospitalisation imprévue ${ }^{8,21,22}$ En outre, les NVPO sont
TABLE V Association entre la présence de pathologies médicales préopératoires et les complications (Données de l'Ambulatory Surgical Unit of The Toronto Hospital, Western Division).

\begin{tabular}{|c|c|}
\hline Conditions médicales & Complications associées \\
\hline Insuf. cardiaque congestive & prolongation du séjour de $12 \%$ \\
\hline Hypertension & $\begin{array}{l}\text { risque } 2 \text { fois plus grand de complica- } \\
\text { tions cardio-vasculaires peropéra- } \\
\text { toires }\end{array}$ \\
\hline Asthme & $\begin{array}{l}\text { risque } 5 \text { fois plus grand de complica- } \\
\text { tions respiratoires postopératoires }\end{array}$ \\
\hline Tabagisme & $\begin{array}{l}\text { risque } 4 \text { fois plus grand de complica- } \\
\text { tions respiratoires postopératoires }\end{array}$ \\
\hline Obésité & $\begin{array}{l}\text { risque } 4 \text { fois plus grand de complica- } \\
\text { tions respiratoires peropératoires et } \\
\text { postopératoires }\end{array}$ \\
\hline Reflux GO & $\begin{array}{l}\text { risque } 8 \text { fois plus grand de complica- } \\
\text { tions liées à l'intubation }\end{array}$ \\
\hline
\end{tabular}

des symptômes très embarrassants pour les patients et qui ont un effet sur leur niveau fonctionnel postopératoire et sur leur satisfaction de la chirurgie et de l'anesthésie ambulatoires. ${ }^{15,23}$

La fréquence des NVPO présente une grande variation selon le type et la durée de l'anesthésie, les médicaments employés, le type de chirurgie et les différentes caractéristiques du patient. Le type d'anesthésie semble être, de ces facteurs, le plus significatif sur l'incidence des NVPO. L'anesthésie générale est associée à la plus forte incidence, le taux le plus haut concernant l'utilisation d'agents d'inhalation. ${ }^{21}$ L'usage des nouveaux agents intraveineux, le propofol en particulier, est associé à une plus faible incidence de NVPO. Les NVPO varient également beaucoup avec le genre de chirurgie (Figure 3). Les patients qui subissent des interventions plus douloureuses, comme elles le sont parfois en ORL, urologie, orthopédie et plastie (par ex. l'augmentation mammaire), sont plus à risque. ${ }^{24}$ Certaines caractéristiques individuelles exposent les patients aux NVPO : le sexe féminin, le jeune âge, l'obésité, les antécédents de mal des transports et de NVPO. Le tabagisme semble en réduire l'incidence. ${ }^{3,21}$

Les NVPO sont fortement associées à la douleur et à son traitement. Les opérations douloureuses sont également associées à de plus haut taux de NVPO et les analgésiques les plus souvent utilisés, les opioïdes, sont de puissants émétiques. Même si la prévention antiémétique n'est pas courante dans les centres de chirurgie ambulatoire, elle est recommandée chez les patients à haut risque. ${ }^{25}$ 


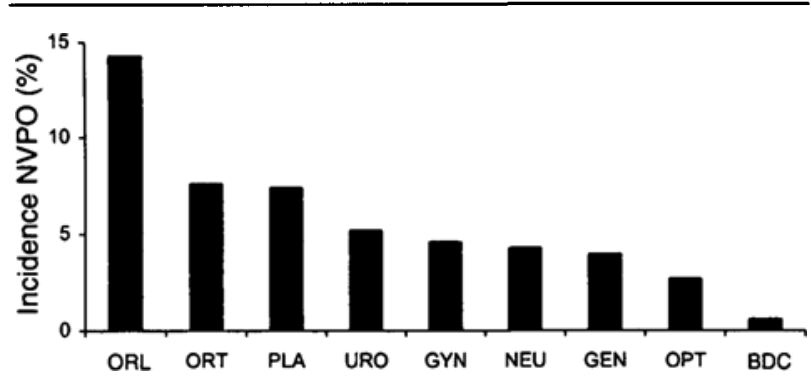

FIGURE 3 Incidence de nausées et vomissements postopératoires (NVPO) selon le type de chirurgie (ORL = oto-rhino-laryngologie, et chirurgie dentaire, ORT = orthopédie, PLA = plastie, $\mathrm{URO}=$ urologie, $\mathrm{GYN}=$ gynécologie, $\mathrm{NEU}=$ neurochirurgie, GEN = chirurgic générale, $\mathrm{OPT}^{\mathrm{T}}=$ ophtalmologie, $\mathrm{BDC}=$ bloc pour douleurs chroniques) (Données de l'Ambulatory Surgical Unit of The Toronto Hospital, Western Division).

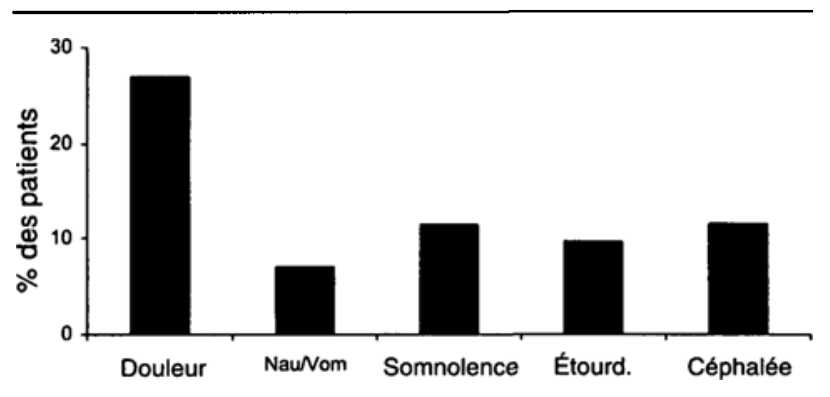

FIGURE 4 Symptômes $24 \mathrm{~h}$ après l'opèration ambulatoire selon l'interview téléphonique ( $\mathrm{n}=778)$. Nau/Vom $=$ nausées/ vomissements

\section{Séquelles mineures}

Les maux de gorge, les tremblements, les étourdissements, la somnolence et les céphalées comptent parmi les complications mineures souvent décrites et négligées qui peuvent aussi entraîner un séjour postopératoire prolongé et influencer grandement la satisfaction du patient et son niveau fonctionnel (Table IV). ${ }^{14,15}$ Les maux de gorge surviennent surtout après l'intubation ou l'usage du masque laryngé. La céphalée est une complication possible après la rachianesthésie, tandis que les étourdissements et la somnolence peuvent être éliminés par une hydratation suffisante. ${ }^{26}$

\section{Les patients âgés et ceux qui présentent des pathologies médicales préexistantes}

Grâce à l'amélioration des techniques anesthésiques et chirurgicales, la chirurgie ambulatoire est devenue

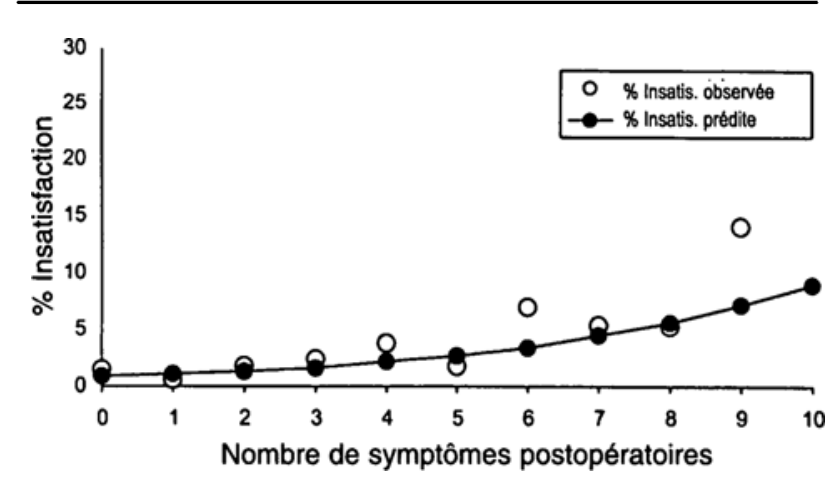

FIGURE 5 Insatisfaction prédite (cercle vides) avec l'anesthésie baséce sur le nombre de symptômes postopératoires.

plus sécuritaire, ce qui facilite l'avènement d'une plus grande diversité d'interventions dans le cadre ambulatoire. Il y a davantage de patients âgés et de patients présentant des antécédents médicaux qui optent pour la chirurgie ambulatoire.

Les gens âgés représentent le segment de la population des centres ambulatoires qui croît le plus rapidement. L'un des principaux avantages de la chirurgie ambulatoire vient du fait qu'elle permet aux patients de retrouver leur environnement habituel et leur mode de vie avec un minimum de dérangement. Cela est particulièrement important pour les plus âgés qui ont moins de capacité d'adaptation aux situations nouvelles et aux changements de leur environnement. Les gens âgés risquent davantage de souffrir de complications cardiovasculaires peropératoires et postopératoires que les jeunes patients, mais ils sont moins susceptibles de connaître d'autres désagréments comme les douleurs excessives, les NVPO, la somnolence et les étourdissements. ${ }^{6}$ Le risque deux fois plus élevé de complications cardiovasculaires chez les patients âgés ne représente pas de contre-indication à la chirurgie ambulatoire, mais souligne l'importance d'un traitement cardio-vasculaire périopératoire approprié.

La présence de certaines pathologies médicales antérieures à l'opération accroît aussi le risque de complications peropératoires et postopératoires (Table V). Les patients atteints d'insuffisance cardiaque congestive connaissent un séjour postopératoire plus long et ceux qui souffrent d'hypertension sont plus à risque de complications cardio-vasculaires. Les fumeurs et les patients obèses et les asthmatiques risquent davantage de subir des complications respiratoires. L'obésité accroît la possibilité de NVPO, tandis que c'est le con- 
traire dans le cas du tabagisme. ${ }^{3,10}$ Ces associations, même si elles n'excluent pas les patients de la chirurgie ambulatoire, devraient rappeler aux anesthésiologistes la nécessité de soins anesthésiques individualisés, adaptés aux caractéristiques propres de chaque patient.

\section{Sejour postopératoire prolongé}

La durée du séjour postopératoire ou le moment du départ de l'hôpital servent souvent à mesurer les résultats de la chirurgie et de l'anesthésie ambulatoires. ${ }^{27-29}$ Ce sont des mesures intermédiaires ou substitut aux "mesures réelles», comme la récupération du patient. Quoique substitut à la récupération, c'est aussi l'une des mesures «réelles», puisque la longueur du séjour postopératoire de l'ensemble des patients a un effet direct sur le coût de fonctionnement des salles de réveil.

La durée du séjour postopératoire peut être mise en corrélation avec la fréquence de complications plus ou moins sévères. Ces complications n'exigent habituellement pas d'hospitalisation, mais elles peuvent retarder de beaucoup le départ du patient. Une récupération facile et un départ hâtif sont des signes de succès, tandis qu'un séjour postopératoire prolongé est signe d'échec, car il peut accroître le coût de l'intervention. Cette mesure simple et directe doit être utilisée avec prudence.

L'heure du départ réel peut être différente du moment où le patient est réellement prêt à partir. Si le moment du départ a des retombées économiques sur les soins postanesthésiques, le temps qu'il faut pour que le patient soit prêt à retourner à domicile reflète bien l'étape de la récupération. La cause de l'écart entre ces deux réalités peut être l'absence d'accompagnateur ou son retard, ou des pratiques inadéquates ou inefficaces au moment de décider du congé du patient. ${ }^{23}$ Il est important de rappeler que le moment du départ est une affaire individuelle et que les patients peuvent partir en toute sécurité une fois qu'ils ont satisfait aux critères établis.

Dans le but d'accélérer les départs rassurants, il faut définir des critères appropriés d'évaluation de l'état du patient. ${ }^{30-32}$ En plus de s'assurer que le patient présente des signes vitaux stables, s'oriente bien et ne souffre pas de NVPO débilitants, de douleurs ou de saignements et est accompagné d'une personne responsable, le patient devrait pouvoir marcher, n'avoir aucun problème d'absorption des liquides et de miction. Toutefois, les critères concernant l'absorption et la miction sont fortement discutés depuis que des études ont montré que des patients ont pu recevoir leur congé sans problème avant de répondre à ces critères. ${ }^{33,34}$

Avec l'emploi d'anesthésiques à action rapide et de techniques chirurgicales à effraction minimale, de nom- breux patients ambulatoires peuvent partir de façon sécuritaire à l'intérieur d'une période d'une ou deux heures, le plus souvent de trois heures., ${ }^{3,832,35}$ Une étude rapporte $82 \%$ et, une autre, $54 \%$ de départs après une période de deux heures ou moins. Lors d'une simulation, on a démontré que seule une importante diminution de la durée moyenne de séjour postopératoire pourrait réduire le coût de fonctionnement de la salle de réveil : le coût étant plus fonction du nombre maximal de patients qui s'y retrouvent simultanément. ${ }^{36}$ Pour changer ce nombre au moyen d'une planification optimale et d'une gestion individuelle appropriée des patients, il faut connaître les facteurs associés à un séjour postopératoire prolongé qui touchent la chirurgie, l'anesthésie et le patient lui-même.

La longueur du séjour postopératoire et l'occurrence d'un séjour prolongé sont surtout influencés par le type d'anesthésie et de chirurgie. ${ }^{8,37}$. L'anesthésie générale, associée à une forte incidence de NVPO (10-50\%), et certaines interventions ORL, orthopédiques et urologiques qui sont souvent plus douloureuses que d'autres, sont associées à un long séjour. ${ }^{12,13,22,24}$ Des douleurs intenses et des NVPO conduisent à des séjours de 3 à 4 fois plus longs. ${ }^{8,12}$ Ces deux complications se produisent chez nombre de patients. D'autres complications, cardio-vasculaires par exemple, de la somnolence et des étourdissements peuvent aussi prolonger le séjour. ${ }^{8}$ Cependant, ces incidents n'affectent que peu de patients et produisent moins d'impact sur la population chirurgicale ambulatoire totale.

Les caractéristiques du patient, comme le sexe et l'âge, sont associées aux complications. Les femmes souffrent davantage de NVPO que les hommes. ${ }^{21}$ Les jeunes patients sont plus susceptibles de ressentir des douleurs excessives et d'avoir des NVPO, tandis que les gens âgés sont plus exposés aux troubles cardio-vasculaires. ${ }^{6}$

\section{Hospitalisation non prévue}

Pouvoir accorder un congé sans risque fait partie des soins chirurgicaux ambulatoires essentiels. L'hospitalisation imprévue représente un fardeau supplémentaire de la chirurgie ambulatoire sur le système des soins de santé. Quand elle survient, les gains obtenus par la chirurgie ambulatoire se trouvent donc perdus.

Parallèlement au séjour postopératoire prolongé, le taux d'admissions non prévues ou non planifiées à la suite d'une chirurgie ambulatoire reflète l'occurrence de complications peropératoires ou postopératoires immédiates. Les taux d'hospitalisation imprévue indiquent habituellement la fréquence de complications sévères, ce qui oblige à garder le patient et à lui prodiguer les soins nécessaires en milieu hospitalier. Les taux d'admissions imprévues vont de $0,3 \%$ à $1,4 \%$.4,9,11,13,16,35 
Les raisons les plus fréquentes d'une hospitalisation non prévue (38-79\%) sont liées à des complications chirurgicales. ${ }^{4,9,11,16}$ Parmi celles-ci, la douleur intense, les saignements et un accident chirurgical sont les plus évoquées. Les complications reliées à l'anesthésie, le plus souvent les NVPO, la somnolence ou les étourdissements et, plus rarement l'aspiration, sont les raisons de $10-26 \%$ des admissions non anticipées. ${ }^{4,9,11,16}$ Dans 6-17\% des cas, les patients sont admis pour des raisons médicales. Ces admissions surviennent soit à cause de la présence ou de l'aggravation de pathologies médicales antérieures, comme le diabète, l'angine et l'apnée du sommeil, soit à cause de problèmes résultant de complications peropératoires ou postopératoires, comme la dysrythmie, l'infarctus myocardique ou le bronchospasme. ${ }^{4,9,11,16}$ Un certain nombre d'hospitalisations imprévues (5-20\%) le sont pour des raisons sociales, comme l'absence d'accompagnateur ou d'aide suffisante à domicile. $4,9,16$

Les patients qui ont subi des interventions douloureuses, en ORL, urologie ou orthopédie, sont susceptibles d'être admis de 4-30 fois plus après l'opération. ${ }^{9}$ Le type et la durée de l'anesthésie permettent également de prédire une hospitalisation non anticipée. Les patients qui ont reçu une anesthésie générale sont de 2 à 5 fois plus à risque d'être hospitalisés que ceux qui ont reçu une autre forme d'anesthésie. La probabilité d'admission augmente avec la longueur de l'anesthésie., 911 Les patients dont l'opération se termine tard dans la journée sont plus sujets à l'hospitalisation. ${ }^{9}$

\section{Visite postopératoire à l'hôpital et réadmission}

Les conséquences de la chirurgie ambulatoire sur les patients et le personnel soignant s'étendent au delà du congé de l'unité de chirurgie d'un jour accordé au malade. Des complications peuvent se développer ou se reproduire une fois le patient à la maison. Alors, pour évaluer totalement la sécurité de la chirurgie ambulatoire et son influence sur les soins de santé, il est essentiel de prolonger les investigations à la période qui suit le congé, évaluant les besoins supplémentaires de soins médicaux.

Des études basées sur un questionnaire ou une interview téléphonique peuvent inclure des renseignements sur toute communication entre un patient et le médecin. La plupart des visites des patients au bureau du médecin sont motivées toutefois par des problèmes mineurs ou sont des visites de contrôle postopératoire. Après une intervention, le retour à l'urgence suivi de l'hospitalisation du patient qui avait reçu son congé annonce des complications plus sérieuses. Les études de patients de chirurgie ambulatoire accordent habituellement un suivi de $24-72 \mathrm{~h}$ après le congé, temps pendant lequel les complications sont plus susceptibles de survenir. ${ }^{4,14,35,38}$ Cependant, pour saisir tous les incidents postopératoires pertinents et pour obtenir une image complète de la chirurgie ambulatoire reliée au retour et à la réadmission à l'hôpital, un suivi plus long, pendant au moins 30 jours, est nécessaire.

Les résultats connus montrent qu'à l'intérieur des 24-72 premières heures, de 4 à $8 \%$ des patients de chirurgie ambulatoire sont vus par un médecin, cette proportion pouvant s'accroître jusqu'à $12 \%$ pendant le premier mois postopératoire. $4,7,35,38$ Les taux de réadmission à l'hôpital sont plus bas, 0-3\%, pendant le premier mois suivant l'intervention ambulatoire. ${ }^{13,17,35,39}$ Dans la dernière et la plus complète de ses études sur la réadmission à l'hôpital après la chirurgie ambulatoire, Twersky et coll. ont trouvé que, malgré la réadmission de $3 \%$ de leurs 6243 patients dans le mois qui a suivi le congé, seulement 1,3 \% l'ont été pour des séquelles des complications. ${ }^{17}$ Les raisons les plus souvent évoquées dans ce cas étaient des saignements, de la fièvre et de l'infection, des douleurs, la déhiscence de la plaie et de la rétention urinaire. Twersky et coll. ont aussi montré que les patients subissant des interventions urologiques étaient plus à risque de réadmission à l'hôpital. ${ }^{17} \mathrm{Ils}$ soutiennent que ce groupe de patients est en soi vulnérable, puisqu'ils sont sujets à présenter des symptômes comme l'hématurie, l'infection et la rétention urinaire, symptômes qui donnent lieu généralement à une hospitalisation.

Dans notre institution, nous avons trouvé que pendant une période de trois ans, seulement $1,1 \%$ des 17 638 patients ont été réadmis en moins de 30 jours suivant une intervention ambulatoire, et seulement pour $13 \%$ d'entre eux, à cause de complications chirurgicales ou médicales. Aucune étude n'a pu identifier de cause anesthésique aux réadmissions.

\section{La satisfaction du patient}

Quoique la satisfaction du patient soit une mesure subjective des soins prodigués, elle est importante, puisqu'elle affecte d'autres résultats thérapeutiques et l'usage des services de soins de santé..$^{23}$ La satisfaction du patient face à la chirurgie et l'anesthésie ambulatoires est généralement élevée, 97-99\% des patients sont satisfaits des soins ambulatoires reçus. ${ }^{13,23,35}$ Les insatisfactions sont liées à des complications peropératoires et postopératoires (par ex. l'anesthésie inadéquate pendant l'anesthésie sous monitorage, les NVPO et les maux de gorge). ${ }^{23}$ Les plaintes sont aussi fortement associées au nombre de symptômes. ${ }^{23}$ 


\section{Niveau fonctionnel postopératoire}

Le retour à un niveau fonctionnel préopératoire (ou pré-maladie) représente le succès réel de la chirurgie et de l'anesthésie ambulatoires. Cependant, après la chirurgie ambulatoire, le niveau fonctionnel postopératoire est atteint ${ }^{14,15,40}$ en fonction de la présence ou non de symptômes. ${ }^{14}$ La présence de douleurs postopératoires sévères ou modérées et de NVPO cause la plus importante perte fonctionnelle $24 \mathrm{~h}$ après la chirurgie (21\%, $9 \%$ et $7 \%$, respectivement). ${ }^{15}$ Swan et coll. ont montré que les patients subissent une perte fonctionnelle pendant les sept premiers jours postopératoires et que seulement $22 \%$ d'entre eux retournent à un travail à temps complet ou partiel le septième jour après l'opération. ${ }^{40}$ Ces résultats suggèrent que, malgré la réduction du coût du personnel réalisée grâce au passage de la chirurgie au soins ambulatoires, une grande partie des frais des soins ou de leur impact est tout simplement passée au patient ou à sa famille.

\section{Conclusion}

La chirurgie ambulatoire, tel qu'on la pratique, présente une fiche excellente concernant la sécurité. La morbidité grave est rare et la mortalité très rare pendant ou après les interventions chirurgicales ambulatoires. Les complications moins importantes, sans danger pour le patient, comme les troubles cardio-vasculaires peropératoires et, plus souvent, les douleurs intenses postopératoires et les NVPO, ont une plus grande occurrence. Ces incidents mineurs peuvent entraîner un séjour postopératoire prolongé, une admission non prévue à l'hôpital ou une réadmission, et ils peuvent aussi affecter la satisfaction du patient et son niveau fonctionnel postopératoire. L'occurrence de ces complications mineures est maintenant l'enjeu le plus important de l'évaluation de la qualité et de la recherche de solutions visant à l'améliorer. L'objectif de réduire l'incidence des complications mineures de la chirurgie ambulatoire peut être atteint en mettant au point des techniques chirurgicales moins effractives, en utilisant de nouveaux agents anesthésiques d'action rapide aux effets secondaires minimaux et en améliorant le traitement des douleurs postopératoires.

\section{Reférences}

(Voir page R25) 